\title{
Concept of Compassion in Buddhism, Its Ethical Implication in the Contemporary World
}

\author{
Dr. Mohd Ashraf Dar \\ Guest Assistant Professor Cluster University Srinagar
}

\begin{abstract}
Buddhism is often considered as a path for purification vissudhimagga. During an era of empire building and extreme asceticism, it advocated a middle path based on moral perfection. Compassion in Buddhism enjoys an exalted position and its embodiment, Bodhisattva is highly venerated. This concept finds its applicability more in the contemporary era of materialistic race and political chaos, degrading social norms and decaying moral values. This paper is an attempt to analyze the possibility of compassion as a tool to restore peace and prosperity in the contemporary world.
\end{abstract}

Keywords: Compassion, Buddhism, Violence, materialistic race, global peace, humanity, terrorism.

DOI: $10.7176 / \mathrm{JCSD} / 49-04$

Publication date:June $30^{\text {th }} 2019$

\section{Introduction:}

Compassion is often defined as a sense of concern that arises when we are confronted with another's suffering and feel motivated to see that suffering relieved. Compassion is the main content of almost all the religions of the world with varying themes and importance.

In Buddhism we come across two terms which carry the content of compassion, Metta and Karuna. In the Theravada Buddhism, we come across the term metta,(Pali) which literally means benevolence, loving-kindness, friendliness and amity according to various scholars of Buddhism. ${ }^{1}$ Mitta is half of the four Brahmaviharas in Buddhism. These are loving-kindness or benevolence, compassion, empathetic joy and equanimity. According to Kalama Sutta, Theravadins believe that once these four states are developed, the person radiates in all four directions. Such a practice leads to purification of one's mind, checks evil induced consequences and leads to happiness in the present life and if the emancipation from the cycle of births is not attained in the present birth and if due to Karma, there is a future birth, it will be in a heavenly realm. According to Acharya Buddharakkhita in the introduction to the translation of metta sutta, it makes one a pure font of well-being and safety for others. Just as a mother gives her own life to protect her child, so metta only gives and never wants anything in return. To promote one's own interest is a primordial motivation of human nature. It is also the shielding and enormously enduring attitude of a mother who tolerates all difficulties for the sake of her child and ever protects it despite its misbehavior. Metta is also the attitude of a friend who wants to give one the best to further one's well-being.

Though compassion is important in all schools of Buddhism, but is particularly emphasized in Mahayana. It is also linked to the idea that acquired merit can be transmitted to others which in turn led to the ideal of Bodhisattva in Mahayana Buddhism. In Mahayana Buddhism, compassion (karuna) holds an extremely important position. The bodhisattvas are the main actors of compassion, Avalokitesvara being foremost among them. In Mahāyāna Buddhism, karuna is one of the two qualities, along with enlightened wisdom (prajna), to be cultivated on the Bodhisattva path. Although having reached enlightenment, bodhisattvas usually makes a vow to postpone entering into nirvana until all other beings have also been saved. They devote themselves to helping others reach enlightenment. This elevation of karuna in Mahayana Buddhism is the basic line of distinction between the Theravada ideal of arhant and the Mahayanic ideal of Bodhisattva. The former ideal longs for the salvation of self while the later longs for the salvation of all. This attitude makes the compassion greater (maha karuna) in Mahayana Buddhism.

\section{Buddhism and Compassion:}

We do not possess a contemporary Biography of Gotama Buddha. Going one step further we may say that such a biography never existed most probably. What we infer from the so called earliest sources and later commentaries is that Buddha was not contended with his own emancipation and longed for the liberation of the suffering humanity. For 45 years Buddha taught a doctrine of friendliness and charity, of renunciation and concentration, of wisdom and compassion, of morality and purity. On seeing an old man, a sick man, a corpse and an ascetic, he was moved to the core. He left his home at the age of 29 and became a mendicant and set out in search of solution for the ills of life. He met many learned philosophers, went for severe austerities with the ascetics. After rigorous austerities for 6 years, he found all these futile and decided to give up such austerities and accepted food offered

\footnotetext{
${ }^{1}$ Peter Harvey, An Introduction to Buddhism: Teachings, History and Practices. Cambridge University Press. (2012) pp. 318-319. Finley P. Dunne, The World Religions Speak on "The Relevance of Religion in the Modern World", Springer (2013) pp. 94-95.
} 
by a girl named Sujata at an age of 35.This incident is believed to have happened in the Gaya District of Bihar on the bank of river Niranjana. After it, Siddhartha sat in concentration under a tree known as Bodhi-tree (Asvattha) and attained bodhi or enlightenment. Karen Armstrong on the authority or Pali texts believe that on this crucial juncture, Gotama remembered his childhood experience of ecstasy. When his father Suddhodhana has taken him away from home to participate in a ploughing festival and where he was left under a rose-apple tree to enjoy the festival. When he saw that the ploughing was uprooting grass with many eggs of insects and their larvae, he felt this pain as his own pain. He felt as his own relatives were being killed. It was like he brought self into it and it seems to have brought a moment of ecstasy, a rapture which takes us outside the body and beyond the prism of our own egotism. ${ }^{1}$ Considering this incident historical, it seems that compassion is the corner stone on which the whole edifice of Buddhism rests.

Buddha never claimed to have laid the foundation of a new religion which we call Buddhism. Buddha called his path as Dhamma. The Buddha stressed that he was not expounding an opinion but a Path, that is, a way of life, based on values and actions that lead to a holistic apperception, an experience, a realization. The Dhamma, as taught by the Buddha, is a path that leads to the cessation of suffering through a lifetime effort to gain insight into essential truths about the human condition. The codified form of these truths is what we call Four Noble truths and Eight Fold path. Ashoka Maurya, one of the greatest patrons of Buddhism also used the term Dhamma in his inscriptions. He even named the officers in charge of religious activities as Dhamma Mahamatyas. His concept of conquest even changed to Dhamma Vijaya. The inscriptions of Ashoka are filled with imkkportance of observing moral values and carrying on compassion. Buddha stressed upon the cultivation of two important qualioties for realization of enlightenment, wisdom (Prajna) and compassion (metta or karuna). According to Barbara O'brien, wisdom and compassion are like two wings that help in flight towards the enlightenment.

An analysis of the Four Noble truths (cattāri ariyasaccāni) and Eight Fold path clearly shows the importance of compassion. Compassion serves in two domains, compassion for self and for others. What Buddha strived for can be understood as the compassion for self. He was rattled by the suffering in many forms which are better described in the four signs he witnessed. The Four Noble Truths are the truth of suffering, the truth of the cause of suffering, the truth of the end of suffering, and the truth of the path that leads to the end of suffering. More simply put, suffering exists; it has a cause; it has an end; and it has a cause to bring about its end. The first truth identifies the presence of suffering $(d u k k h a)$. It indicates the imperfection of human nature, which further may indicate the imperfection of this world as well. During our lifetime, we inevitably have to endure physical suffering such as pain, sickness, injury, tiredness, old age, and eventually death. It implies that we are never able to keep permanently what we strive for. Joys are followed by sorrow and so on. It shows a strong sense of pity on the ignorance of those who consider this world everlasting and the joys of life eternal. The Second Truth, on the other hand, seeks to determine the cause of suffering. The cause of suffering is called samudaya. Desire and ignorance are the chief causes of suffering. Desire refers to craving pleasure, material goods, and immortality, all of which are wants that can never be satisfied to the desired level. Consequently, even desiring them can only bring suffering. Ignorance implies not being able to grasp the world as it is. It means the illusionary nature of world. Vices, such as greed, envy, hatred and anger, derive from this ignorance. This noble truth is also full of compassion as it depicts the merciful attitude towards the fellow beings becoming prays to the desire and ignorance. The third noble truth arouses a solution to the suffering. It brings a hope that the suffering can be eradicated. It is also a form of compassion in which we give hope to somebody who is in distress. The fourth noble truth gives the eight fold path as a remedy to overcome suffering.

The Eight Fold path is completely based on compassion in many ways. It includes the Right Understanding or Right View. This is a significant step on the path as it relates to seeing the world and everything in it as it really is, not as we believe it to be or want it to be. Merely knowing reality is of very little value if we don't put it to practice in our lives. The second step on the Eightfold Path is Right Intent. This step is a commitment to the path. The first step makes us aware about the reality while this step makes our intentions to accept the reality shown by the preceding step. In other words it develops a passion of walking on the path cleared by the first step. Right speech involves recognition of the truth. Communicating thoughtfully helps to unite others, and can heal dissention. By resolving never to speak unkindly, or in anger, a spirit of consideration evolves which moves us closer to everyday compassionate living. Right Action recognizes the need to take the ethical approach in life, to consider others and the world we live in. This includes not taking what is not given to us, and having respect for the agreements we make both in our private and business lives. Right livelihood means the occupation which is not harmful for others. Right Effort means cultivating an enthusiasm, a positive attitude in a balanced way. Right Mindfulness means being aware of the moment, and being focused in that moment. Right Mindfulness is closely linked with meditation and forms the basis of meditation. It is not an attempt to exclude the world, in fact, the opposite. Right Mindfulness asks us to be aware of the moment, and of our actions at that moment. Right Concentration is turning the mind to focus on an object, such as a flower, or a lit candle, or a concept such as

\footnotetext{
${ }^{1}$ Karen Armstrong, Buddha, Paw Prints, Tokyo (Japan), 2008, p.68.
} 
loving compassion.

What Buddha attained after a hard struggle of 7 years is the Four Noble truths and the Eight Fold path. Initially his struggle aimed at understanding the cause of the suffering at individual level. He wished to free himself from the suffering he witnessed in the form of four signs. Once he attained the enlightenment or the remedy for the suffering, he didn't kept it for himself alone rather he preached it to the people in order to make them free from the bond of suffering as he wished for himself. The very teaching of the Dhamma to the people is the highest degree of compassion itself. In the Mahayana Buddhism, Bodhisattva became the embodiment of compassion especially the Avalokitesvara who is considered the Bodhisattva of infinite compassion. Mah〉y na Buddhists advocate universal compassion, which is nondiscriminatory and active in all contexts. This, naturally, reflects a distinctive worldview. As Charles Taylor argued, moral reactions "seem to involve claims, implicit or explicit, about the nature and status of human beings. a moral reaction is an assent to, an affirmation of, a given ontology of the human. ${ }^{1}$ Even in Jatakas which are tales about the previous births of Buddha, we find compassion as the dominant feature in the form of the Monkey King, Deer King and the Wounded Swan. Compassion is reflected in each and every aspect of the Buddha's life which reaches its culmination in the teaching of the Dhamma.

\section{Ethical Implications}

The message of Buddha through his Dhamma is a way of life keeping away from all evil deeds, cultivation of life by doing good deeds and purification of mind from mental impurities. An analysis of the teachings of Buddha leads to the conclusion that everything in this world is inter-related and thus inter-dependent. For being happy, compassion is necessary. According to Buddhism, compassion can be viewed in two phases as mundane side and higher spiritual side. The mundane side of compassion is found in leaders and people in positions of power; an ideal example being King Asoka who experienced it. He was deeply moved by compassion after realizing the massacre of the Kalinga war. It is to be noted here that in accordance with the teaching of the Buddha, if a ruler goes against the Buddhist ethics in a cruel manner towards his subjects, then the state declines. The Cakkavatti sãhanàda sutta illustrates the idea of a righteous monarch in vivid detail. This kind of mundane aspect of compassion is a common thing. We are moved by the destitute and needy and we are inspired by the feeling of mundane compassion to help them in whatever possible way. It may be either material assistance or any other form of help. On the other hand, the higher spiritual side of compassion is different, because it is only found in the Buddhas and Arahats who first realized it by themselves in full and then begin to help others. They have no more attachment to the worldly life. That is why the Buddha teaches the method of compassion from the mundane side to the higher level compassion which is known as Mahà Karuṇa ${ }^{2}$

Buddha strived hard to attain enlightenment, or in other words the revolution in self, but he didn't kept it limited to self rather out of compassion preached it to others, in other words he initiated an outer revolution for the happiness at a much wider level (universal). Thus, for instance, he preached the fundamental oneness and unity of mankind, irrespective of color or race and created a revolution for the abolition of the caste system which was prevalent in India in his days. In order to demonstrate his concept of the oneness of mankind, he moved not only with kings and capitalists and aristocratic ladies, but also with the poorest of the poor, with beggars and scavengers, robbers and courtesans. He did not retire from the world after his Enlightenment lived for forty-five years in the community, constantly seeking out those whom he could help.

From the four noble truths, it becomes apparent that the cessation of suffering leads to peace or ultimate happiness. Peace and happiness are directly proportional to each other. This peace is generated once the selfcompassion is developed. The contemporary world is distraught with fears and threats of wars. Countries involved in war have become awesome arsenals of military hardware, ensuring continued business and profit to merchants of death and destruction: Following conflicting ideologies, not only military personnel but thousands of innocent men, women and children are being mercilessly massacred and incalculable damage is inflicted on land and property. Nothing escapes the fury and the frenzy of battle. Hatred, greed and anger are at the base of this violence. Buddha declares in Dhammapadda 'Hatred never ceases by hatred,' declared the Buddha, 'but only by love', and again, 'Victory breeds ill-will, for the conquered are unhappy. ${ }^{3}$ In many other parts of the world, war-clouds hang menacingly near. The air is full of violence in thought, word and deed. Only compassion and loving kindness can stop it. In the contemporary world, the most powerful is one who has the most capacity to destroy. This in turn has led to a race for accumulation of more and more deadly weapons like nuclear weapons. If compassion had not left our souls, we would have been nefarious towards such thinking which aims at mass destruction and seeking pleasure in destroying others including humans as well as other abiotic and biotic constituents of our environment. This greed has resulted in a curse in the form of global warming, destructive cyclones and floods and drought.

Compassion is needed at all levels of human activity whether that is a family, a small business establishment

\footnotetext{
${ }^{1}$ Charles Taylor, Sources of the Self: The Making of Modern Identity, (Cambridge, MA: Harvard University Press, (1989), p.5.

${ }^{2}$ Ven. Pantu Chakma, Compassion and Its Ethical Value as Depicted in Early Buddhism, Chinese Buddhist Encyclopedia, Proceedings of The third International Conference Buddhism \& Australia 2014.

${ }^{3}$ The Dhammapada, Tr. Acharya Buddharakkhita, Buddhist Publication Society Kandy, Sri Lanka, Verse.5.
} 
or at national and international level. If our policies regarding the governance are based on compassion, the world will become truly a paradise. Even we can cite an example in the form of Asoka who adopted the concept of dharma-vijaya after the bloodshed of Kalinga war. The concept of kingship that develops with compassion is paternal in nature.

Compassion finds its implication in the diverse fields of modern society. In society, economy, environment, polity and international relations. In social matters, compassionate approach leads to a prosperous family devoid of domestic violence and other domestic evils. If compassion develops in the society, it will be free from the heinous crimes like use of drugs and other intoxicants, rape, murder and theft. It will lead to a prosperous society based on mutual help and love. It will lead towards a society where the fundamental rights are respected. The main social evils like violence at many levels, use of intoxicants and drugs, family breakdown, exorbitant usury and female infanticide are all due to ignorance and greed. Compassion aims at eradication of the root causes of these evils which in turn may lead towards a crime free society.

\section{Analysis}

Compassion is natural and hence it is almost the main content of every religion. In Buddhism it enjoys a much venerated status as discussed above. There are almost seven countries in the world with majority of Buddhist population like Cambodia 96.90\%, Thailand 93.20\%, Myanmar (Burma) 87.90\%, Bhutan 74.70\%, Sri Lanka $70.2 \%$, Laos 66\% and Mongolia 55.1\%. As per the report of Violent Death Project, the violent death rate in Buddhist countries is 4\%. ${ }^{1}$ According to United Nations Office on Drugs and Crime (UNODC) report of 2015 murder rates (per 100,000 inhabitants) in the major Buddhist countries is as: Cambodia 1.84, Thailand 3.21, Myanmar 2.84, Bhutan 2.75, Sri Lanka 2.91, and Laos 6.87and Mongolia 7.23. The worst violence that came to fore front in the 2017, was the ethnic cleansing of Rohingya Muslims in Myanmar's Rakhine Province. Almost 5,00,000 Rohingyas were forced to migrate from Myanmar out of which 40,000 migrated to India.. Some elements in India are toiling hard to deport back them to Myanmar.

Is Buddhism responsible for all these crisis? It seems insane to held Buddhism as a religion responsible for this inhuman act. Compassion is in every religion, but still we see violence rampant throughout the world. Dalai Lama, the spiritual Head of Tibetan Buddhism on 11, September 2017 said that Buddha would have been with Rohingya Muslims or the victims of violence. Religion is aimed at bringing harmony between man and man and between his environments. Religion covers almost all the aspects of humanity especially the moral aspects. Then why religion is the main agency behind the acts of violence or terrorism? One important thing about the message of Buddha is that he adapted a middle path Madhyamika Magga in his age which was an age of great empire building on one hand and of great asceticism on other hand. It is extremism and fundamentalism that is leading the human race towards catastrophe. An analysis of all the major religions of the world reveals the compassionate aspect more stressed, but still we find extremism and fundamentalism in almost all the religions of the world. Fundamentalism is an approach to a religion's doctrine where its beliefs are enforced so strictly and literally that they are no longer compatible with the real-world as it is today. In a way, religion is exploited for the socio-political aims. Religious fundamentalism or extremism is based on the narrow understanding of a religion. In Myanmar, the extremist Buddhists used the concept of rebirth which is a philosophical concept against the very basic concept of wisdom and compassion to unleash a reign of terror on Rohingyas. They propagated that the Rohingya Muslims are the incarnations of harmful insects and reptiles which need cleansing. It is against the very basic ideals of Buddhism where compassionate behavior is prescribed for even the abiotic components of the environment.

\section{Conclusion}

From the above discussion it becomes apparent that like other religions Buddhism has a strong concept of compassion. Buddhism prescribes compassion like one of the two wings of a bird for flight towards emancipation. Compassion is not only a religious concept but it is a natural concept. It is an inborn feeling in all the beings whether humans or other animals. In the contemporary world, religion is often considered a bondage. Compassion is a common instinct that can join the masses of the world irrespective of caste, color, religion and ethnicity. Compassion will make us to understand that we are the members of a world community and it is the responsible of all the human beings to make this world prosperous. We believe that a compassionate world is a peaceful world. Compassion is not just a warm feeling. Karen Armstrong, one of the most eminent Religious historian sees it as an urgent and global imperative. In 2008, the TED Prize winner, called for the creation of a Charter for Compassion, a document with the Golden Rule at its ethical core. Designed to unite people globally, the charter was drafted by a diverse set of religious leaders and launched in November 2009 to inspire people around the world to restore compassion, empathy and kindness to the center of life. A compassionate world is possible when every man, woman and child treats others as they wish to be treated--with dignity, equity and respect.We believe that all human beings are born with the capacity for compassion, and that it must be cultivated for human beings to survive

\footnotetext{
${ }^{1}$ http://violentdeathproject.com/random-comparisons, Accessed on 02-020-2018
} 
and thrive.

\section{References}

1. Peter Harvey, An Introduction to Buddhism: Teachings, History and Practices. Cambridge University Press. (2012).

2. Finley P. Dunne, The World Religions Speak on "The Relevance of Religion in the Modern World", Springer (2013)

3. Karen Armstrong, Buddha, Paw Prints, Tokyo (Japan), 2008.

4. Charles Taylor, Sources of the Self: The Making of Modern Identity, (Cambridge, MA: Harvard University Press, (1989)

5. Ven. Pantu Chakma, Compassion and Its Ethical Value as Depicted in Early Buddhism, Chinese Buddhist Encyclopedia, Proceedings of The third International Conference Buddhism \& Australia 2014.

6. The Dhammapada, Tr. Acharya Buddharakkhita, Buddhist Publication Society Kandy, Sri Lanka.

7. http://violentdeathproject.com/random-comparisons, Accessed on 02-020-2018

8. https://www.ted.com/participate/ted-prize/prize-winning-wishes/charter-for-compassion , Accessed on 3001-2018 